SHS Web of Conferences 6, 03013 (2014)

DOI: $10.1051 /$ shsconf / 20140603013

(C) Owned by the authors, published by EDP Sciences, 2014

\title{
The Construction of Evaluation Index System of Food Safety under Two-Factor Theory
}

\author{
You Shibing ${ }^{\text {a }}$, Ren Jingru, Zhang Hang, Tian Haofeng \\ School of Economics \& Management, Wuhan University, 430072 Wuhan Hubei, China
}

\begin{abstract}
Food safety is a significant livelihood issue. A thorough comprehensive evaluation index system of food safety is constructed based on two-factor theory from the perspective of solving large social tensions and transforming the economic development pattern. The system has bottom line indicator of hygiene factors and improving indicator of incentive factors. The proposed index system can achieve the integration of appraisal, supervision and management and meet the demand of government, enterprises and the public.
\end{abstract}

Keywords. food safety; evaluation index system; Two-factor theory

\section{Introduction}

Food safety is a significant livelihood issue which concerns thousands of households. It is related to extensive subjects, which directly leads to its high demand for evaluation system based on scientific, rational and sustainable principles. There are many methods for the construction of evaluation system of food safety ${ }^{[1]}$, such as Liu Yuxun ${ }^{[3]}$ has established and perfected comprehensive evaluation system of food safety by "grey analytical hierarchy process" according to food safety in quantity, quality and sustainability; Chen Qin ${ }^{[4]}$ has introduced advanced HACCP (Hazard Analysis Critical Control Points System) to analyze the process of food safety evaluation and establish the layer of structure of the process of food safety evaluation in quality, taking yeast engineering for example; Lin Xiang ${ }^{[5]}$ analyzed the result of comprehensive evaluation of food hygiene supervision and constructed the supervision system of food safety evaluation by AHP (Analytic Hierarchy Process).

The development of the society demands for comprehensive and perfect evaluation system for food safety. However, researches on evaluation index of food safety, domestic or overseas, are simplex and deficient. At present, our country is in urgent need of the change of the economic development mode, constructing perfect and comprehensive evaluation system for food safety is to meet the need of socio-economic development, is to meet the need of health environment for the development of food enterprises, and is to meet the need of realizing people's happy life and building harmonious social atmosphere. This paper aims to explore how to construct comprehensive evaluation index system for food safety based on two-factor theory.

\section{New perspectives on definition of evaluation system for food safety and evaluative features}

\footnotetext{
a Corresponding author: sbyou@whu.edu.cn
} 
With the bloom of China's economy, people's living standards have been significantly improved, thus people pay more attention to the quality of food than the quantity ${ }^{[2]}$. In recent years, food safety incidents - such as Sudan red, contaminated milk powder, gutter oil, gelatin problem and so on-frequently happen, which lead to sharp rising of mass disturbance. As for causes for this phenomenon, on one hand, these conflicts in our society may lead to contradiction, or disordered interaction between people may lead to a state of tension which gives rise to excessive pressure ${ }^{[6]}$; on the other hand, it is related to the deficient development of economic development mode in our country. Thus, economic structural adjustment, especially in the process of food circulation, is the most important point in reforms concerning food which is proposed in Fifth Plenary Session.

In the process of easing social tension and changing economic development mode, we should consider this problem at a new historical height, implement scientific outlook on development and construct a people-oriented harmonious society. The new definition of the evaluation of food safety is eliminating (or controlling) these internal and external threats and hidden troubles in the process of researching and developing, producing, circulating and using of food and medicine to make sure that users have no potential risks in a short period and then ease the social tension and reach a safe state of sustainable development in food and medicine by the cooperation between the government, enterprises and the public.

According to the new definition of food safety, we consider the following three aspects as evaluation features of evaluation index system for food safety: (1)assuring people's health and life safety; (2)easing social tension; (3)considering "Four Promotion and Three Reduction" (Promoting the public's sense of security, promoting the public's lifetime, promoting the public's sense of happiness, promoting social service level, reducing the incidence of diseases, reducing the cost of production and reducing the price of food and medicine) as our aim and changing economic development mode to reach the sustainable development of food safety.

\section{Two-factor theory and its application in evaluation system of food safety}

Two-factor theory which is also called motivator-hygiene theory is firstly introduced by American behaviorist Fredrick Herzberg in Motivators in Work in 1959. He had done a lot of researches and found out that there were direct and indirect factors in employee motivation. According to different effects to motivation, Herzberg divided these factors into two categories: the first is hygiene factors; the second is incentive factors, that is, the so called two-factor theory.

\subsection{The effect of two-factor}

According to Herzberg's theory, hygiene factors which generally include regular administrative management in companies, supervision, working conditions, salary and so on, can only eliminate people's dissatisfaction, but can neither satisfy people nor motivate them. The lack of hygiene factors will contribute to dissatisfaction. People will feel dissatisfaction and be fed up with work when the lack of hygiene factors is beyond the limit of workers' tolerance. When hygiene factors reaching normal level, workers' feeling of satisfaction can only help maintain their regular work and workers will not be motivated if these factors are increased. Thus, hygiene factors are also called maintenance factors.

Incentive factors, including sense of achievement in work, recognition degree of work performance, duty responsibilities, professional development and growth and so on, are these factors which can make people satisfy with their work. People will neither feel satisfied nor dissatisfied without incentive factors. The effect of incentive factors is to motivate workers and make them feel satisfied. Workers' work efficiency will be remarkably increased when there are enough incentive factors. While if managers don't provide workers with incentive factors, they will also continue to maintain regular work just without feelings of satisfaction. Thus, incentive factors are also called 
promotion factors

\subsection{The replacement and application of two-factor theory in food safety evaluation system}

The application of two-factor theory in food safety evaluation system divides the system into two parts: hygiene factors act as baseline system in food safety evaluation, while incentive factors act as promotion system in food safety evaluation. There are significant differences between these two systems in their evaluation subjects, measurement index and functions.

\subsubsection{The implication of the replacement of two-factor theory in food safety evaluation system}

According to two-factor theory, food safety evaluation system is divided into two parts to be replaced: one is hygiene factors are replaced as baseline system; while the other is incentive factors are replaced as promotion system. In traditional thought mode towards food safety, there is only satisfied or dissatisfied, or security or insecurity. There is a breakthrough in the two-factor theory inherent concept of thinking, the baseline evaluation system defines food security as there is only "unsatisfactory" and "no unsatisfactory", or "unsafe" and "no insecurity." In the food safety evaluation, we must firstly meet the requirements of the baseline system, Although the increase of hygiene factors, that is, the baseline system cannot improve the quality of food, there is no possibility to further the evaluation of food safety if the requirements of baseline system cannot be met; secondly, we should make good use of the promotion system. We can evaluate the objects by higher evaluation index when we evaluate the basic performance of food safety. Incentive factors, that is, promotion system is the terminal target of food safety evaluation work.

\subsubsection{Functions of two-factor theory in food safety evaluation system}

The first system is base line system, which is the foundation framework of food safety evaluation. Whether the basic framework meets standards of food safety determines the implementation of the hoisting system. The base line system consists of subjective performance (mainly the subject of law enforcement) and objective performance. In subject, the basic investigation target is food supervision and management departments, while the chief evaluation object is the performance of local governments. In object, the food safety evaluation related to "regulatory object safety" is directly. "The performance of administrative counterparts" refers primarily to the performance of enterprises. And the evaluation of a company focuses on security status of food research and development, production and circulation.

The second system is hoisting system. It is the reflection to higher requirements of specific effect of food safety evaluation while satisfying the base line system. The standards of the second system are the "social tension" of food issues and the "sustainable development" on food. It is the reflection in building human-oriented society and the implementation of scientific outlook on development in the field of food safety. The index, "social tension" of food safety evaluation, mainly used to show that how well the public know about the food safety regulations and the adverse reaction density on food issue, and to measure the remission conduct and capability of official departments and enterprises on existing or potential food safety issues. Based on the transformation of economic development model and adjustment of economic structure, the index of "sustainable development on food" is used to inspect that whether the administrative counterparts can develop sustainably, which means whether they pave the path on long-term economic development and the harmonious development between man and nature and in the transformation of development mode the overall situation is profit or not. At the same time, it also investigates the conducts and abilities of government departments related to food safety in cultivating the sustainable development of administrative counterparts

\section{Food safety evaluation index and system architecture}


A complete food safety evaluation system includes four systems of food safety management, baseline system which considers government, enterprises and the public as examination subjects and promotion system, which can achieve the integration of food safety assessment, supervision and management.

\subsection{Food safety management system}

Food safety management system includes: (1) Food safety organizations security system. It mainly evaluates whether there is an effective multi-branch coordinating body tissue or not, and also evaluate the existence of food safety regulatory loopholes within the organization and functions of the test area, whether the functions of the various departments is clear, and also the existence of regulatory vacuum , overlapping functions and so on. On food safety inspection agency, whether the division of work is clear or not, effective coverage, detection of overlapping functions and other conditions. (2) Food safety laws and regulations system. Evaluation index system of laws and regulations will examine the laws and regulations in common areas, but not the regional ones. It pays attention to whether the existing laws and regulations are effective implemented or not. (3) Food safety management system. Security system is to deal with supervision in all chains of food production and circulation which can eliminate the hidden risks before they happen and effectively protect the public from these risks ${ }^{[7]}$. (4) Quality management system of food safety. Food quality which is the key point of food safety evaluation, includes the system of standards of production, quality certification system, self-test system in enterprises and the food and drug recall system.

\subsection{Food safety evaluation index system}

The specific index of food safety comprehensive evaluation system which is composed of these safety evaluation management systems and relative setting put above, also includes the choice of examination subjects of the government, enterprises, and the public, baseline system and promotion system in food evaluation system which is replaced by hygiene factors and incentive factors according to two-factor theory. The index can be referred in table 1:

Table 1. At all levels of evaluation index

\begin{tabular}{|c|c|c|c|c|c|}
\hline \multicolumn{2}{|c|}{$\begin{array}{c}\text { Classification of } \\
\text { Evaluation Subjects }\end{array}$} & $\begin{array}{l}\text { Classificat } \\
\text { ion of } \\
\text { Index } \\
\text { System }\end{array}$ & $\begin{array}{l}\text { First-Grade } \\
\text { Index }\end{array}$ & Second-Grade Index & Third-Grade Index \\
\hline \multirow{4}{*}{$\begin{array}{c}\text { Governme } \\
\text { nt }\end{array}$} & \multirow{4}{*}{$\begin{array}{l}\text { The } \\
\text { Behavior of } \\
\text { Local } \\
\text { Governmen } \\
\text { ts }\end{array}$} & \multirow{4}{*}{$\begin{array}{l}\text { Baseline } \\
\text { Index }\end{array}$} & \multirow{3}{*}{$\begin{array}{l}\text { The Degree of } \\
\text { Attention of } \\
\text { Local } \\
\text { Government } \\
\text { and Superior } \\
\text { Departments }\end{array}$} & $\begin{array}{l}\text { Evaluation of } \\
\text { Government's Supporting } \\
\text { Input }\end{array}$ & $\begin{array}{l}\text { (1) Total investment of supporting funds of } \\
\text { local government per year (proportion) } \\
\text { (2) Non-monetary input of local governments }\end{array}$ \\
\hline & & & & $\begin{array}{l}\text { Evaluation of Equipment } \\
\text { of Local Government } \\
\text { Commissioners } \\
\text { (Organizations) }\end{array}$ & $\begin{array}{l}\text { (1) The level of local government } \\
\text { commissioners (organizations) } \\
\begin{array}{l}\text { (2) The number of local government } \\
\text { commissioners }\end{array}\end{array}$ \\
\hline & & & & $\begin{array}{l}\text { Evaluation of Equipment } \\
\text { of Functional } \\
\text { Departments } \\
\text { Commissioners }\end{array}$ & $\begin{array}{l}\text { (1) The quality level of commissioners in } \\
\text { functional departments } \\
\text { (2) The scale of commissioners in functional } \\
\text { departments }\end{array}$ \\
\hline & & & $\begin{array}{l}\text { The Perfection } \\
\text { of Security } \\
\text { System of } \\
\text { Food Safety in } \\
\text { Local } \\
\text { Governments }\end{array}$ & $\begin{array}{l}\text { Evaluation of abilities of } \\
\text { Coordination and } \\
\text { Supervision in Food } \\
\text { Safety Related } \\
\text { Multi-Branches in Local } \\
\text { Governments }\end{array}$ & $\begin{array}{l}\text { (1) State of food safety organizational system } \\
\text { perfection } \\
\text { (2) Times of joint law enforcement } \\
\text { (examinations) between multi-branches per } \\
\text { year (quarter) }\end{array}$ \\
\hline
\end{tabular}




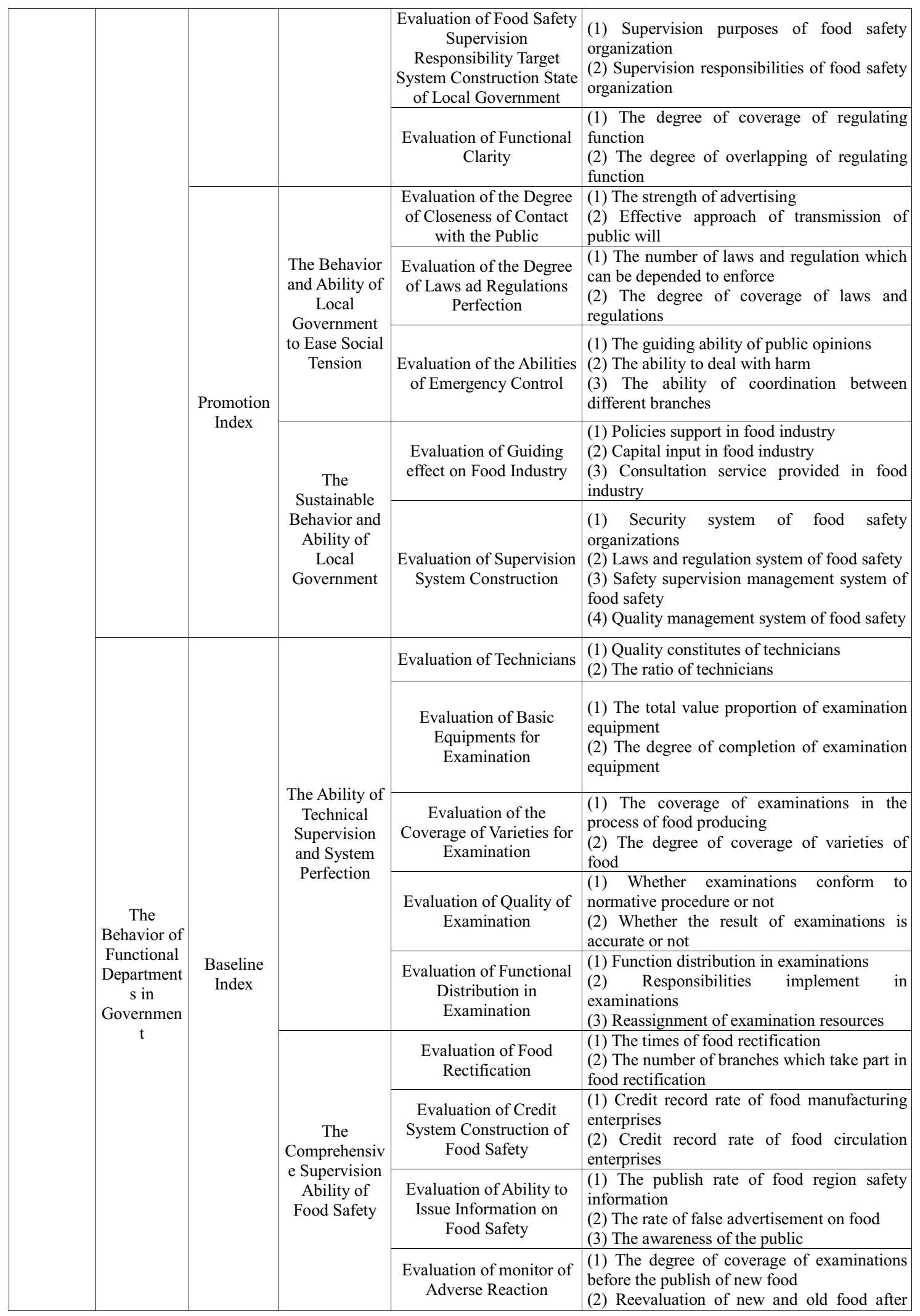




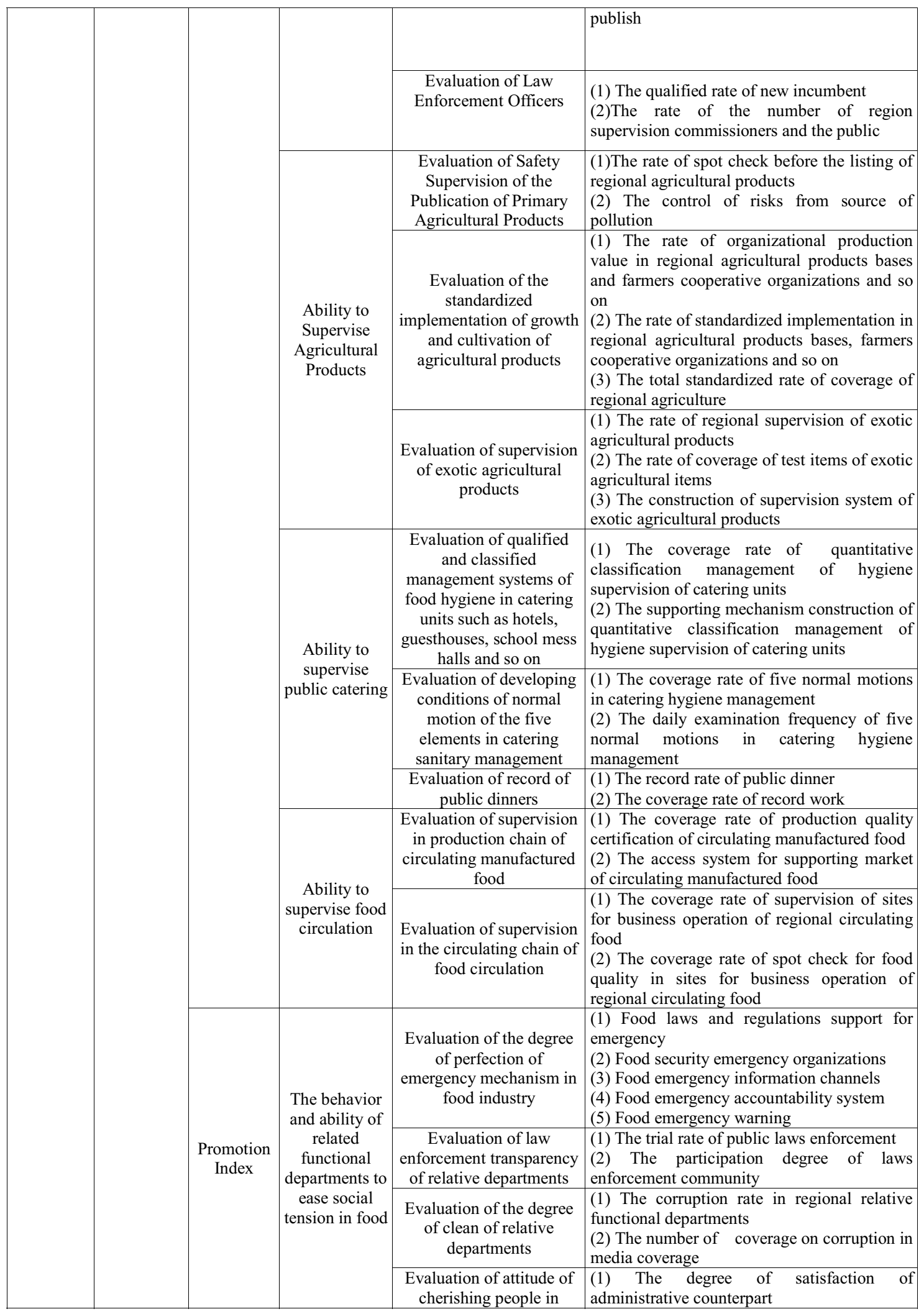


IFSRAP 2013

\begin{tabular}{|c|c|c|c|c|}
\hline & & & functional departments & $\begin{array}{l}\text { (2)The effective processing rate of the public } \\
\text { demands }\end{array}$ \\
\hline & & $\begin{array}{c}\text { The } \\
\text { sustainable }\end{array}$ & $\begin{array}{c}\text { Evaluation of government } \\
\text { informationization } \\
\text { construction }\end{array}$ & $\begin{array}{l}\text { (1)The degree of information integration } \\
\text { (2)The coverage of government } \\
\text { informationization }\end{array}$ \\
\hline & & $\begin{array}{l}\text { ability of } \\
\text { functional } \\
\text { departments }\end{array}$ & $\begin{array}{l}\text { Evaluation of talents } \\
\text { training in food industry }\end{array}$ & $\begin{array}{l}\text { (1) The number of relevant training in } \\
\text { functional departments } \\
\text { (2) Government's investment in the food } \\
\text { industry training for talents }\end{array}$ \\
\hline & & $\begin{array}{l}\text { Public } \\
\text { catering }\end{array}$ & $\begin{array}{l}\text { Basic evaluation on } \\
\text { catering service units }\end{array}$ & $\begin{array}{l}\text { (1) The certificate holder rate in catering } \\
\text { enterprises } \\
\text { (2) Qualified classification of regional } \\
\text { catering enterprises } \\
\text { (3) The five permanent members of } \\
\text { management checks compliance rate }\end{array}$ \\
\hline & & service units & $\begin{array}{c}\text { Evaluation on stock } \\
\text { channels of raw materials }\end{array}$ & $\begin{array}{l}\text { (1) Notes traceability } \\
\text { (2) The degree of market supply specification }\end{array}$ \\
\hline & & & $\begin{array}{c}\text { Evaluation of the security } \\
\text { level of regional catering } \\
\text { food }\end{array}$ & $\begin{array}{l}\text { (1) The qualified rate of catering examinations } \\
\text { (2) The certificate holder rate of catering } \\
\text { enterprises }\end{array}$ \\
\hline & & & \begin{tabular}{|c|} 
Safety evaluation of \\
primary agricultural \\
products before the listing
\end{tabular} & $\begin{array}{l}\text { (1) Sampling compliance rate before the } \\
\text { listing of agricultural products } \\
\text { (2) Control of risks from source of pollution }\end{array}$ \\
\hline & & $\begin{array}{l}\text { The behavior } \\
\text { of production } \\
\text { subject of } \\
\text { agricultural } \\
\text { products }\end{array}$ & $\begin{array}{l}\text { Evaluation on degree of } \\
\text { standard reaching in } \\
\text { plantation, growth and } \\
\text { organization of } \\
\text { agricultural products } \\
\end{array}$ & $\begin{array}{l}\text { (1) The degree of systematization } \\
\text { (2) The coverage rate of standardized } \\
\text { implement }\end{array}$ \\
\hline & Index & & $\begin{array}{l}\text { Evaluation of self-control } \\
\text { system perfection of } \\
\text { agricultural products }\end{array}$ & $\begin{array}{l}\text { (1) The system for agricultural products } \\
\text { self-tests } \\
\text { (2) The system for agricultural products recall } \\
\text { (3) The system for quality certification }\end{array}$ \\
\hline Administrative & & & \begin{tabular}{|c|} 
Evaluation on the \\
standard reaching of \\
production of circulating \\
manufactured food \\
\end{tabular} & $\begin{array}{l}\text { (1) Sample qualified rate of distribution and } \\
\text { processing of food production } \\
\text { (2) Passing rate of enterprises which reach } \\
\text { standards }\end{array}$ \\
\hline $\begin{array}{c}\text { Counterpart-Enterprise } \\
\mathrm{s}\end{array}$ & & $\begin{array}{l}\text { The behavior } \\
\text { of food } \\
\text { enterprises for }\end{array}$ & $\begin{array}{l}\text { Evaluation of standard } \\
\text { reaching of hygiene in } \\
\text { circulation channels }\end{array}$ & $\begin{array}{l}\text { (1) The certificate coverage rate of HACCP of } \\
\text { circulating channels } \\
\text { (2) The enterprises holding rate of } \\
\text { certification for hygiene }\end{array}$ \\
\hline & & $\begin{array}{l}\text { (and } \\
\text { circulating } \\
\text { manufacture) }\end{array}$ & $\begin{array}{l}\text { Evaluation of standard } \\
\text { reaching of products } \\
\text { examinations in the chain } \\
\text { of circulating }\end{array}$ & $\begin{array}{l}\text { (1) The qualified rate of products sample spot } \\
\text { check } \\
\text { (2) The qualified proportion of sampling in } \\
\text { enterprises }\end{array}$ \\
\hline & & & $\begin{array}{c}\text { Evaluation of the } \\
\text { self-control system } \\
\text { construction in circulating } \\
\text { food enterprises }\end{array}$ & $\begin{array}{l}\text { (1) The system for self-test in the process of } \\
\text { circulating manufactured food } \\
\text { (2) The system for circulating food recall } \\
\text { (3) The system for quality qualification }\end{array}$ \\
\hline & & & $\begin{array}{l}\text { Evaluation on harmonious } \\
\text { degree between } \\
\text { environment and the } \\
\text { development of relative } \\
\text { enterprises }\end{array}$ & $\begin{array}{l}\text { (1) GDP energy consumption in food } \\
\text { enterprises } \\
\text { (2) Cost of environmental protection facility } \\
\text { input } \\
\text { (3) The recycle rate of resources } \\
\text { (4) The mechanism for resources recycle }\end{array}$ \\
\hline & $\begin{array}{l}\text { Promotion } \\
\text { Index }\end{array}$ & $\begin{array}{l}\text { The } \\
\text { sustainable } \\
\text { development } \\
\text { behavior of }\end{array}$ & $\begin{array}{l}\text { Evaluation on the relative } \\
\text { enterprises' research and } \\
\text { development input into } \\
\text { products }\end{array}$ & $\begin{array}{l}\text { (1) The input into research and development } \\
\text { of products } \\
\text { (2) The input efficiency of research and } \\
\text { development }\end{array}$ \\
\hline & & $\begin{array}{l}\text { relative } \\
\text { enterprises }\end{array}$ & $\begin{array}{l}\text { Evaluation on relative } \\
\text { enterprises' sense of } \\
\text { social responsibilities }\end{array}$ & $\begin{array}{l}\text { (1) The number of operation which violates } \\
\text { laws and rules } \\
\text { (2) The distribution of credit rating }\end{array}$ \\
\hline & & & $\begin{array}{l}\text { Evaluation of the } \\
\text { implement of relative } \\
\text { enterprises' brand } \\
\text { strategies }\end{array}$ & $\begin{array}{l}\text { (1) Rate for brand planning } \\
\text { (2) Expense for advertising input }\end{array}$ \\
\hline
\end{tabular}




\begin{tabular}{|c|c|c|c|c|}
\hline & & & $\begin{array}{l}\text { Evaluation on the degree } \\
\text { of advanced production } \\
\text { and management in } \\
\text { relative enterprises }\end{array}$ & $\begin{array}{l}\text { (1) Advanced production and management } \\
\text { adoption rate } \\
\text { (2)The rate of senior personnel in preparation }\end{array}$ \\
\hline & & & $\begin{array}{l}\text { Evaluation on the appeal } \\
\text { degree of relative } \\
\text { enterprises }\end{array}$ & $\begin{array}{l}\text { (1) The number of demands of regional } \\
\text { administrative counterpart } \\
\text { (2) The efficient response rate of regional } \\
\text { administrative counterpart }\end{array}$ \\
\hline & & \multirow{2}{*}{$\begin{array}{l}\text { The behavior } \\
\text { and ability to } \\
\text { ease food } \\
\text { safety in } \\
\text { relative } \\
\text { enterprises }\end{array}$} & $\begin{array}{l}\text { Evaluation of relative } \\
\text { social sense of } \\
\text { responsibilities }\end{array}$ & $\begin{array}{l}\text { (1) The production and management rate } \\
\text { which violates laws and rules } \\
\text { (2) The distribution of credit level }\end{array}$ \\
\hline & & & $\begin{array}{c}\text { Evaluation on relative } \\
\text { ability and attitude to deal } \\
\text { with emergency }\end{array}$ & $\begin{array}{l}\text { (1) The preparation rate of contingency plan } \\
\text { in enterprises } \\
\text { (2) The number of safety training in } \\
\text { enterprises }\end{array}$ \\
\hline \multirow{10}{*}{ The Public } & \multirow{8}{*}{$\begin{array}{l}\text { Promotion } \\
\text { Index }\end{array}$} & \multirow{4}{*}{$\begin{array}{l}\text { The public's } \\
\text { social tension } \\
\text { behavior }\end{array}$} & $\begin{array}{c}\text { Evaluation on mass } \\
\text { disturbance }\end{array}$ & \\
\hline & & & \begin{tabular}{|c|} 
Evaluation of satisfied \\
degree towards food from \\
the public
\end{tabular} & \\
\hline & & & $\begin{array}{l}\text { Evaluation of authority } \\
\text { and impartiality of } \\
\text { functional departments } \\
\text { from the public } \\
\end{array}$ & \\
\hline & & & $\begin{array}{l}\text { Evaluation on appeal } \\
\text { degree of the public }\end{array}$ & \\
\hline & & & $\begin{array}{c}\text { Evaluation on expectation } \\
\text { for food safety of the } \\
\text { public }\end{array}$ & \\
\hline & & $\begin{array}{l}\text { The public } \\
\text { factors } \\
\text { contributing to }\end{array}$ & \begin{tabular}{|c|}
$\begin{array}{c}\text { Evaluation on expectation } \\
\text { for the quality of food } \\
\text { products of the public }\end{array}$ \\
\end{tabular} & \\
\hline & & $\begin{array}{c}\text { food } \\
\text { sustainable } \\
\text { development }\end{array}$ & $\begin{array}{c}\text { Evaluation on expectation } \\
\text { for the effects of food } \\
\text { products of the public }\end{array}$ & \\
\hline & & & \begin{tabular}{|l} 
Evaluation of the \\
promotion of the public's \\
awareness of food safety
\end{tabular} & \\
\hline & Baseline & $\begin{array}{l}\text { The basic } \\
\text { awareness of }\end{array}$ & $\begin{array}{c}\text { Evaluation on the public's } \\
\text { awareness of safety and } \\
\text { right-protection }\end{array}$ & \\
\hline & Index & food safety & $\begin{array}{c}\text { Evaluation of the public's } \\
\text { common sense of food } \\
\text { safety }\end{array}$ & \\
\hline
\end{tabular}

This food safety evaluation system which is established based on the two-factor theory, not only provides the government with various baseline index and promotion index for self-examination and supervision for enterprises, but also can collect information from enterprises and the public to strengthen management by formulate proper policies which will help realize the integration of examination, supervision and management with the participation of three sides.

\section{Conclusion}

According to Herzberg's two-factor theory, this article introduces the concept of hygiene factors and incentives into food safety evaluation system which will enhance food safety issues to a higher level; and the pursuit of food security is no longer just "not a problem". The hygiene factors in two-factor theory are the baseline. Its contained index is the policies index which can only eliminate people's dissatisfaction and solve the baseline problems in food safety to satisfy people in a short period of time. Incentive factors are the most critical intrinsic motivation. Only when people's demands are satisfied, can they be motivated to develop sustainably.

Food is one of the important factors causing social tension, and also an important part of structural 
transformation of the economy. On the ground of excessive tension in the society and the transformation of economic development mode, food safety evaluation system cannot be limited to traditional research methods. The introduction of two-factor theory has brought new ideas for the food safety assessment system which can help improve and benefit the stable development of economy, social harmony and people's lives and health.

\section{References}

1. Xi Weidong, Shi Yuyue, Tian Wei. The Reviews for Evaluation of Food Safety[J]. Food Engineering, 2007(2), P3-5.

2. Deng Wencong, Zhu Xuedong, Wang Junneng. Brief Introduction to Food Safety Evaluation and Its Methods[J]. Livestock and Poultry Industry, 2009(242), P8-10.

3. Liu Yuxun. Hierarchy and Grey Analsis of The Synthetical Evaluation Index System of Food Security[J]. Journal of Henan University of Technology(Natural Science Edition), 2007, 28(5), P 53-57.

4. Chen Qin . Hazard Analysis Critical Control Point System on Food Safety Evaluation and Its Application in Fermentation Industry[J]. Journal of Zhengzhou Grain College,1998, 19(3), P 87-92.

5. Lin Xiang. Application of Analytic Hierarchy Process (AHP) to Evaluate the Effect of Food Sanitation Supervision Work Comprehensively[j]. Chinese Journal of Health Statistics.1994,16(2), P100-101.

6. Zhang Yong, Zhao Xiaoxia. Social Work Development and Personnel Training under Social Structure of Tension[J]. Forward Position,2012(13), P137-139.

7. Donald E.Kling ner, John Nalbandian. Public Personnel Management:System and Strategy[M]. Beijing: China Renmin University Press, 2001. 